\title{
EFFECT OF ORGANIC AND INORGANIC SOURCES OF NUTRIENTS ON THE BIOACTIVE COMPOUNDS AND ANTIOXIDANT ACTIVITY OF TOMATO
}

\author{
AinA, O. E. ${ }^{*}{ }^{*}$ Amoo, S. O. ${ }^{2}-$ MugivhiSA, L. L. ${ }^{1}-$ OlOwOYo, J. O. ${ }^{1}$ \\ ${ }^{l}$ Department of Biology, Sefako Makgatho Health Sciences University, Pretoria, South Africa \\ ${ }^{2}$ Agricultural Research Council, Vegetable and Ornamental Plants, Rodeeplaat, South Africa \\ *Corresponding author \\ e-mail: woleaina@yahoo.com; phone: +27-12-521-3947
}

(Received 21 ${ }^{\text {st }}$ Dec 2018; accepted 20 ${ }^{\text {th }}$ Feb 2019)

\begin{abstract}
The study was conducted to compare the levels of bioactive compounds and antioxidant activities of (Solanum lycopersicum var. cerasiforme) fruits cultivated on different soil amendments (cow dung, chicken droppings and ([40 g/kg N: $60 \mathrm{~g} / \mathrm{kg} \mathrm{N}: 40 \mathrm{~g} / \mathrm{kg} \mathrm{N}]$ Nitrogen-Phosphorus-Potassium) in a shaded house. Tomato seedlings were transplanted into pre-treated soils and watered daily in the afternoon for a period of five months. The general growth and yield performances were in the order of NPK > Chicken droppings > Cow dung. The fruits were harvested at maturity (red-ripened stage) and subjected to bioactive compounds analysis using High Performance Liquid Chromatography (HPLC). The results of the study showed strong relationship between the level of macronutrients like nitrogen, phosphorus and potassium in the soil and the level phenolics, flavonoids, beta-carotene and lycopene contents in tomato. The level of beta-carotene was significantly higher $(\mathrm{p}<0.05)$ in the fruits cultivated in the NPK amended soil which was totally different to the result of other bioactive compounds like phenolics, flavonoids, and lycopene which recorded their highest concentrations in the fruits harvested from control and cow dung amended soil. Antioxidant activity was determined by adding 2,2-diphenyl-1picrylhydrazyl to an aliquot of methanolic extract. The ability to scavenge radical was measured by reading the decrease in purple coloration of the solution using Ultraviolet-Visible (UV) Spectrophotometer. The tomato fruit from cow dung showed highest percentage of radical scavenging activities.
\end{abstract}

Keywords: abiotic and oxidative stress, acetate shikimate pathway, cow dung, physiological changes, reactive oxygen species

\section{Introduction}

The use of chemical fertilizer has been a popular and widespread practice in the effort to address global food security challenge resulting from low fertile agricultural soil. The dependence on these chemical fertilizers, particularly nitrogen fertilizer has become necessary to replenish soil nutrients and invariably improve the quantity and quality of agricultural produce. High crop yield and high biomass of plant from $\mathrm{N}$ fertilizer application are responsible for increasing dependent on $\mathrm{N}$-fertilizer (Camara et al., 2003; Guo et al., 2010). However, intensive usage of $\mathrm{N}$-fertilizer has been reported to cause accumulation of nitrogen residues, nutrient toxicity, metal pollution, greenhouse gas emission, groundwater contamination and soil acidification (Han and Zhao, 2009; Sierra et al., 2015). Furthermore, research has shown that increase in applied nitrogen leads to increase in the soil electrical conductivity, available nitrogen, distortion of $\mathrm{C} / \mathrm{N}$ ratio, distorting soil microbial community and reduction in nutritional quality of agricultural produce (Stuart et al., 2014; Sierra et al., 2015; Norman and Dazzo, 2016; Wei et al., 2018). It has been established that crops only take up 30-50\% 
of chemical fertilizers and the remaining percentage are lost to the environment (Norse, 2005; Mózner et al., 2012).

Conversely, the use of organic manure, has been reported to improve biological, chemical and physical properties of the soil and invariably increase plant growth and yield because of its high organic matter content due to high microbial activity (Stephen et al., 2014; Mitran et al., 2017). Organic manure, as opposed to inorganic fertilizer has also been reported to increase the level of secondary metabolites like phenolic, flavonoid, and antioxidant activity in plant (Zeinab et al., 2013; Fließbach et al., 2007). For example, Wiebel et al. (2000) reported a 19\% higher phenolic content for organically produced apples compared to the inorganically produced ones. Higher level of phenolic content was also recorded for organically grown strawberries compared to inorganically cultivated ones (Hakkinen and Tomonen, 2000). All these reported cases have led to growing preference by consumers for organic agricultural produce (Hughner et al., 2007; Mie, et al., 2016). All over the world, attention has now shifted towards the use of organic manures because of the perceived health benefits and higher nutritional contents believed to be derived from products from these types of farming (Worthington, 2001; Magkos et al., 2001; Tarozzi et al., 2006). This submission is supported by the studies which reported that the positive attitude of the consumers towards organic food is based on their perception of higher nutritional contents and better tasting of organic food compared to the conventional or inorganic foods (Hunter et al., 2011; Smith-Springer et al., 2012). Organic manures are said to enhance antioxidant activity and bioactive compounds like phenol, flavonoid, beta-carotene and lycopene contents of fruits and vegetables (Dumas et al., 2003; Mohd et al., 2013). The beneficial effects of these plant bioactive compounds range from giving fruits their quality tastes and distinct colors in the case of phenolic and lycopene compounds, to their nutraceutical properties such as prevention of degenerative and carcinogenic diseases (Johnson et al., 2014; Canene-Adams et al., 2005). These reported reasons and benefits of organic farming have prompted scientists and farmers to embark on the use of organic manures in the cultivation of agricultural crops, fruits and vegetables.

However, there are a lot of reports which contradicts the suggestion of superior nutritional quality of organic produce over conventional ones. This study was therefore setup to investigate the effects of these different nutrient sources on the nutritional quality of Solanum lycopersicum var. Cerasiforme commonly known as tomato.

Tomato is a fruit bearing herbaceous plant grown annually for its many nutritional contents. It is an important fruit with a wide range of reported health benefits and cultivated in all continents except Antarctica (Ilahy et al., 2011; Pinela et al., 2012). It is one of the cheapest and most readily available sources of proteins, minerals, vitamins and essential amino acids (Stephen et al., 2014), and is said to be rich in antioxidants and bioactive compounds such as phenolics, flavonoids, beta-carotene and lycopene contents which are reported to serve as endogenous defense mechanisms produced in response to pathogens (Pinela et al., 2012; Bhowong et al., 2009; Simova-Stoilova et al., 2008). The concentration level of these bioactive compounds has been linked with the system of production. The effort to reduce the negative impacts of mineral fertilizers on the environment and the increasing demands of consumers for tomato fruit due to its nutritional and health benefits have caused scientists and growers to device means of meeting the demand for quality produce. This study was therefore conducted to compare the effect of organic manures and chemical fertilizer on the growth rate and the levels of bioactive compounds in tomato. 


\section{Methodology}

A farming experiment was set up at the production unit of Sefako Makgatho Health Sciences University located in the northern part of Pretoria (Tshwane metropolitan) South Africa, on a coordinate $\left(25^{\circ} 37^{\prime} 8^{\prime \prime}\right.$ and $\left.28^{\circ} 1^{\prime} 22^{\prime \prime} \mathrm{E}\right)$. The study area experiences a climate of long hot, rainy summer and a short cool and dry winter with an average annual temperature of $18^{\circ} \mathrm{C}\left(65.7^{\circ} \mathrm{F}\right)$.

\section{Experimental design and planting}

The farming experiment was carried out in the summer period of September 2015 March 2016. The study was conducted on red beefsteak tomato with a globe shape fruit, smooth and glabrous skin and weighs between $0.12-0.18 \mathrm{~kg}$. The design comprised three different soil amendments (cow dung, chicken droppings and Nitrogen-PhosphorusPotassium (NPK) fertilizer with a control experiment of soil with without any amendment. The experimental design consisted of comparable amounts of $0.15 \mathrm{~kg}$ of inorganic amendment (NPK fertilizer) manufactured by Omina Fertilizers Johannesburg, South Africa was purchased from a registered marketer, Plantland Kwikery Akasia Pretoria North, South Africa. The dry organic amendments (cow dung and chicken droppings) were collected from a registered livestock farm De-Wildt Brits Road North west South Africa. The $0.15 \mathrm{~kg}$ weight of the $\mathrm{N}_{40} \mathrm{P}_{60} \mathrm{~K}_{40}$, i.e. $\mathrm{N}_{40}$ is $40 \%$ Nitrogen, $\mathrm{P}_{60}$ is $60 \%$ phosphorus and $\mathrm{K}_{40}$ is $40 \%$ potassium used as the basis for the comparison of the organic amendments falls within the recommended doses of NPK fertilizer for the cultivation of tomato (Hebbar et al., 2004). The experiment was a randomized block design which contained 32 pots, each with a $22 \mathrm{~cm}$ diameter (Alain et al., 2013) divided into four groups which were each filled with $5 \mathrm{~kg}$ of sandy-loam soil mixed with $0.15 \mathrm{~kg}$ of the amendment. The first group were each filled with an equal quantity of soil mixed with dry $0.15 \mathrm{~kg}$ of cow dung; the second group contained equal quantity of soil thoroughly mixed with dry $0.15 \mathrm{~kg}$ of chicken droppings; the third group were filled with the same quantity of soil thoroughly mixed with $0.15 \mathrm{~kg}$ of pellet $\mathrm{N}_{40} \mathrm{P}_{60} \mathrm{~K}_{40}$ fertilizer and the last group contained pot plants each filled with equal quantity of soil without any treatment which served as the control. The soils were continuously watered and turned over at two weeks interval with garden forks and left for over a month after the addition of the treatments for proper mineralization of the amendments to take place (Ayeni, 2014). The Pot plant saucers/ trays were placed under the perforated bottom pots to prevent nutrient loss by runoff during irrigation. The seedlings of tomato at two weeks old purchased from a registered nursery, Plantland Kwikery Nursery Akasia Pretoria North were transplanted into each pot plant and watered daily using a measuring cylinder with each plant receiving the same volume of water enough to moist the soil and the plants and preventing runoff.

\section{Soil nutrients}

The soil is a sandy loamy with $71 \%$ sand, $15 \%$ silt and $14 \%$ clay. The control and cow dung amended soils were low in total $\mathrm{N}$, available $\mathrm{P}$ and exchangeable $\mathrm{K}$ compared to NPK and chicken droppings treated soils (Table 1).

\section{Data collection}

Parameters such as plant height, stem girth and leaf area index were recorded for the determination of growth performance of tomato plants from different amendments and the 
control following the procedure of (Stephen et al., 2014). The Plant height was measured using a meter rule. Stem girth was recorded by using a vernier caliper and the leaf area index was measured by determining the average of the distances between the two longest and the two shortest branches using a meter rule (Witness et al., 2016).

Table 1. Composition of soil nutrients

\begin{tabular}{c|c|c|c}
\hline Treatments & Total N $(\%)$ & Available P $(\boldsymbol{\mu g} / \mathbf{g})$ & Exchangeable K $(\boldsymbol{\mu g} \mathbf{g})$ \\
\hline Cow dung & 0.8 & 552 & 535 \\
Chicken droppings & 1.2 & 647 & 443 \\
NPK & 1.8 & 670 & 456 \\
Control & 0.6 & 518 & 376 \\
\hline
\end{tabular}

\section{Preparation of tomato fruit for phytochemical and antioxidant activity analyses}

Tomato fruits from soil treated with different amendments and that of the control were harvested after ripening. Visually selected injury free, ripened fruits were picked and immediately transferred to the laboratory where they were cut into small pieces and homogenized. The homogenates were then frozen in a $-80{ }^{\circ} \mathrm{C}$ refrigerator and freezedried for the phytochemical and antioxidant activity analyses.

\section{Extraction and determination of free radical scavenging activity}

The methanolic extraction was carried out by sonicating the mixture of $100 \mathrm{ml}$ of $50 \%$ methanol into an Erlenmeyer flask containing $6 \mathrm{~g}$ of freeze-dried powdery sample for $60 \mathrm{~min}$. The resulting solution was thereafter filtered through a Whatman No. 1 filter paper and the filtrate (extract) placed in fume cupboard for $24 \mathrm{~h}$ for a complete evaporation of methanol. The determination of free radical scavenging activity was done by following the procedure described by (Biehler et al., 2010). An aliquot (10 mg) of methanolic extract was dissolved in $1 \mathrm{ml}$ of $50 \%$ methanol from which $30 \mu \mathrm{l}$ of the solution was pipetted into an Eppendorf tube. This was made up to $750 \mu$ l volume to which $750 \mu 1$ of 2,2-diphenyl-1-picrylhydrazyl (DPPH) was added. The solution was incubated for $40 \mathrm{~min}$ in the dark at room temperature. The decrease in the purple coloration of the reaction mixtures was read at $517 \mathrm{~nm}$ using an Ultraviolet-Visible Spectrophotometer (SPECORD 210 PLUS). Ascorbic acid was used as the standard and methanol used for extraction served as a negative control. The assay was performed in triplicate and the radical scavenging activity (RSA) was calculated using Equation 1:

$$
\operatorname{RSA}(\%)=A_{0}-\frac{A_{1}}{A_{0}} \cdot 100
$$

where $\mathrm{A}_{0}$ is the absorbance of the control and $\mathrm{A}_{1}$ is the absorbance of the sample.

\section{Beta-carotene and lycopene contents}

Extraction and quantification of $\beta$-carotene were done using the method described by (Moyo et al., 2017). Samples were extracted with ice-cold hexane: acetone (1:1, v/v). The mixture was vortexed before centrifuging at $2000 \mathrm{rpm}$ for $2 \mathrm{~min}$ and the organic phase decanted into another test tube containing $5 \mathrm{ml}$ sodium chloride solution. The 
residue was similarly re-extracted and was combined in the saturated sodium chloride solution each time until the extract was colorless. The separated organic phase was injected into a High-Performance Liquid Chromatography (HPLC) equipped with a Photodiode Array Detector (PDA) and a mobile phase consisted of (7:2:1) acetonitriledichloromethane-methanol with an injection volume of $20 \mu 1$ and detection at $450 \mathrm{~nm}$. Peak identification and quantification were achieved with comparison to authentic $\beta$ carotene standard which was used for the plotting of the calibration curve (Moyo, et al., 2017).

\section{Total phenolic}

The method described by Singleton et al. (1999) was used for the extraction and the determination of the total phenolic content. An aliquot $(10 \mathrm{ml})$ of $50 \%$ methanol was added into an Erlenmeyer flask containing $0.2 \mathrm{~g}$ of the freeze-dried tomato sample and the mixture sonicated for $30 \mathrm{~min}$. The resulting solution was subsequently centrifuged in a HERMLE Z513 at $2000 \mathrm{rpm}$ for $2 \mathrm{~min}$. About $50 \mu 1$ of the supernatant was pipetted into a new test tube and $450 \mu \mathrm{l}$ of distilled water, $450 \mu \mathrm{l}$ of $1 \mathrm{~N}$ folin ciocalteu reagent, $125 \mu \mathrm{l}$ of sodium carbonate solution were added. The solution was vortexed and incubated for $40 \mathrm{~min}$ at room temperature. Different aliquots of gallic acid $(0.1 \mathrm{mg} / \mathrm{ml})$ was used as the standard for plotting the calibration curve and total phenolic content was expressed in $\mathrm{mg}$ gallic acid equivalents (GAE) per g dry weight.

\section{Flavonoid content}

The flavonoid content was quantified using aluminum chloride colorimetric method as described by (Zhisten et al., 1999). An aliquot $(0.2 \mathrm{~g})$ of the freeze-dried tomato sample was weighed into an Erlenmeyer flask into which $10 \mathrm{ml}$ of $50 \%$ methanol was added and the mixture sonicated for $30 \mathrm{~min}$. The solution was then vortexed and centrifuged at $2000 \mathrm{rpm}$ for $2 \mathrm{~min}$ and the supernatant pipetted into a new test tube. About $250 \mu 1$ of the supernatant was pipetted into a new test tube and $1 \mathrm{ml}$ of distilled water, $75 \mu \mathrm{l}$ of $5 \% \mathrm{NaNO}_{2}$ were added. After $5 \mathrm{~min}, 75 \mu \mathrm{l}$ of $10 \% \mathrm{AlCl}_{3}, 500 \mu \mathrm{l}$ of $1 \mathrm{M}$ $\mathrm{NaOH}$ and $600 \mu \mathrm{l}$ of distilled water were added and the solution vortexed. Different aliquots of gallic acid $(1 \mathrm{mg} / \mathrm{ml})$ catechin was used as standard for the calibration curve and flavonoid content was expressed in $\mathrm{mg}$ catechin equivalents (CE) per $\mathrm{g} \mathrm{DW}$.

\section{Statistical analysis}

All statistical analyses were performed using SPSS 24.0 by carrying out analysis of variance to determine the statistical significance and post hoc test using Tukey for the separation of the means of growth performance, bioactive compounds and scavenging activity from the different treatments.

\section{Results}

\section{Effect of different soil amendments on the growth and yield performances}

The results of the growth and yield performances were presented in Tables 1 and 2 (Aina et al., 2018). Although, plants from control soil and cow dung amended soil recorded higher plant height and canopy size at the early stage after transplanting. This observation according to literature, may be due to the physiological adjustment of plant 
to the new environment (Ayeni et al., 2014). Overall, the tomato cultivated in inorganic fertilizer (NPK) recorded the best growth rate which was determined by recording the height, canopy size and stem girth of the plant. Similarly, the yield results showed that NPK produced the highest number of tomato fruits, followed by chicken droppings and with a yield pattern of NPK > chicken droppings > cow dung > control. This yield result is also consistent with other study which suggested that it may be a result of deficiency and or slow mineralization of nutrient of organic manure during the plant growing and developmental stages (de Ponti et al., 2012).

\section{Effect of different soil amendments on the level of bioactive compound concentrations}

The varied level of bioactive compounds of the tomato fruits as influenced by different soil amendments are presented in Table 2. The results showed that the level of phenolics, flavonoids, and lycopene were lower in the fruits harvested from inorganic NPK fertilizer compared to their counterparts from the control and cow dung amended soil. The difference in the level of phenolics flavonoids and lycopene in the fruits cow dung manures, NPK and control soil were statistically significant, the difference in the lycopene across different treatments was statistically significant. However, in reverse pattern, beta-carotene (Fig. 1) was significantly higher in fruit harvested from the soil treated with NPK fertilizer compared to the ones from the rest of the amendments and control. Finally, although the tomato fruit from cow dung amended soil recorded the highest concentration of potential radical scavenging activity, there was however no significant difference in the radical scavenging activity of the fruits across the group (Fig. 2).

\section{Discussion}

It has been suggested that nitrogen stimulates more roots production which in turn enhance plant growth and yield performance (Sultana et al., 2012; Rai et al., 2013). The study done by Mani et al. (2002) reported higher plant height and yield in plant cultivated with NPK fertilizer and attributed this observation to higher $\mathrm{N}$ and $\mathrm{P}$ contents. Chemical fertilizer like NPK has been reported to increase plant biomass and crop yield due to its richness in $\mathrm{N}$ and $\mathrm{P}$ contents which are reported to promote growth in plant (Ekbic et al., 2010; Zeng et al., 2011; Stephen et al., 2014; Mishra and Singh, 2006). The growth result of the current study is consistent with all these previous observations. In this study, application of NPK fertilizer enhances plant height, stem girth and leaf area index considered to be key factors in determining growth vigor. The higher growth response of tomato may be due to the higher nitrogen $(\mathrm{N})$ and phosphorus (P) contents in the NPK compared to other treatments (Table 1).

This observation corroborates previous findings that NPK and poultry manure recorded better yield compared to control and cow dung (Znidarcic et al., 2007; Hague, 2012). The better growth rate and yield performance of NPK and chicken droppings compared to the cow dung and control could be due to the high content of essential nutrients like $\mathrm{N}$ and $\mathrm{P}$ in poultry manure which have been reported to enhance photosynthetic activity capable of promoting root development, vegetative growth and crop yield (John et al., 2004; Lima et al., 2012; Isah et al., 2014; Nafiu et al., 2011; Meysam et al., 2017). 
Table 2. The mean concentration of bioactive active compounds in response to different soil treatments with different letter( $(s)$ indicating significant difference at $95 \%$ confidence interval

\begin{tabular}{c|c|c|c}
\hline Treatments & $\begin{array}{c}\text { Phenolics } \\
\text { (mg GAE/g DW) }\end{array}$ & $\begin{array}{c}\text { Flavonoids } \\
(\mathbf{m g ~ C E} / \mathbf{g ~ D W})\end{array}$ & $\begin{array}{c}\text { Lycopene } \\
\text { (mg/100 g DW) }\end{array}$ \\
\hline Cow dung & $3.90^{\mathrm{a}}$ & $0.40^{\mathrm{b}}$ & $129.76^{\mathrm{b}}$ \\
Chicken droppings & $3.20^{\mathrm{b}}$ & $0.27^{\mathrm{c}}$ & $114.50^{\mathrm{d}}$ \\
NPK & $3.81^{\mathrm{a}}$ & $0.34^{\mathrm{b}}$ & $123.21^{\mathrm{c}}$ \\
Control & $3.91^{\mathrm{a}}$ & $0.56^{\mathrm{a}}$ & $132.66^{\mathrm{a}}$ \\
\hline
\end{tabular}

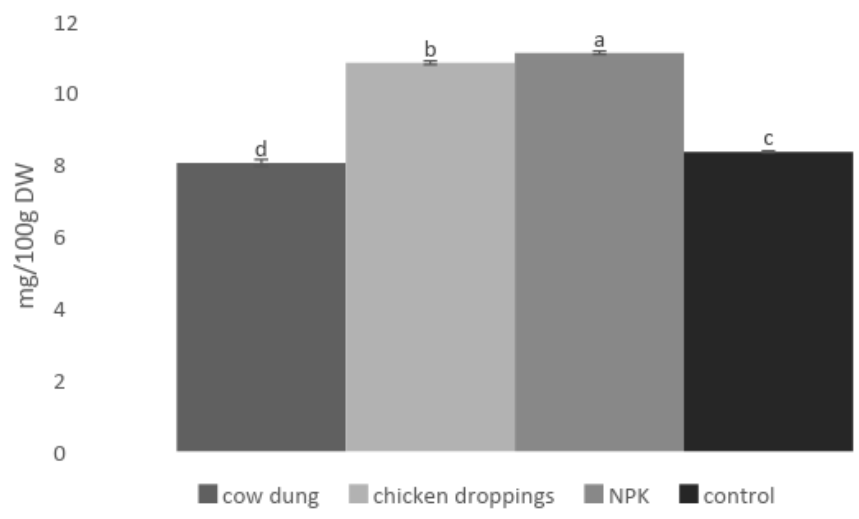

Figure 1. The level of beta-carotene in tomato fruits with different letters indicating significant differences $(p<0.05)$

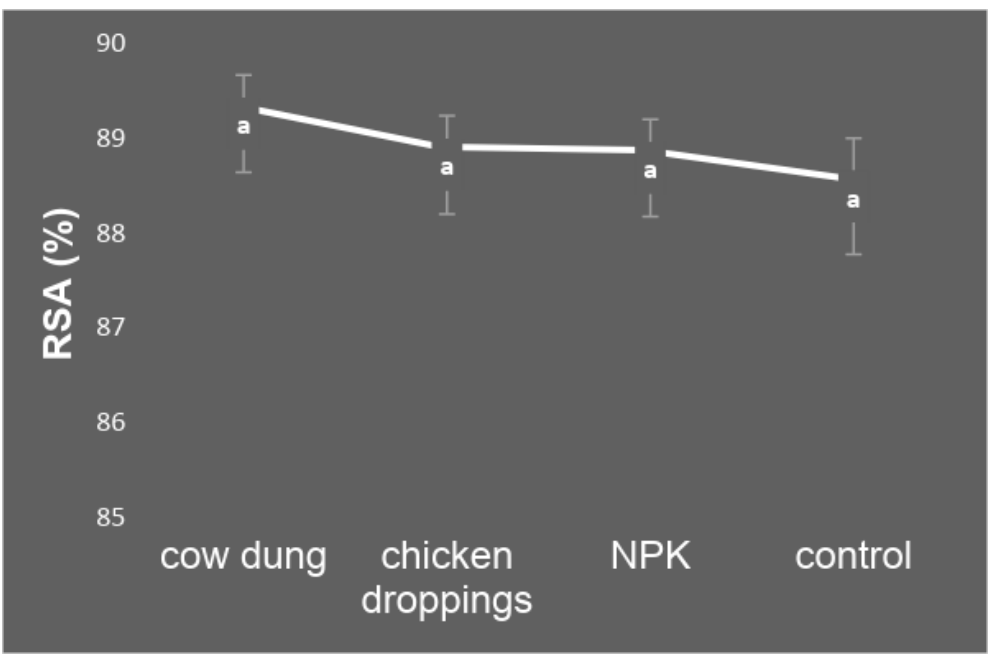

Figure 2. Free radical scavenging activity of tomato fruits same letter indicating no significant difference $(p>0.05)$

On the other hand, organic manures are reportedly less concentrated nutrient sources compared to mineral or chemical fertilizers and are noted to be very slow in mineralization rates, leading to lower nutrient bioavailability during growth and development nutrients demanding stages (Zhao, et al., 2009; Lester and Saftner, 2011; 
Seufert et al., 2012). This condition causes organically cultivated tomato to experience; 1. oxidative stress from superoxide dismutase which is a key enzyme in plant defense and development (Chang et al., 2008), and 2. abiotic stress which causes accumulation of Reactive Oxygen Species (ROS) that inhibits enzymatic activity, disturbs cellular homeostasis and ruptures membrane with deleterious effects on plant growth (Luis, 2015; Baxter et al., 2014). Consequently, organically grown vegetables react to this condition by activating their own defense mechanisms which leads to the synthesizing of more bioactive and antioxidant compounds (Vallverdu-Queralt et al., 2011). They activate signaling pathway for the detoxification of ROS by synthesizing antioxidant that scavenges on ROS (Sharma et al., 2012).

It is therefore conceivable that the result of this study which showed the tomato fruits cultivated in control and organic cow dung amended soils producing higher phenolic, flavonoid and lycopene contents in comparison to their counterparts from chicken droppings and especially inorganic NPK fertilizer amended soil corroborates these reports. The cow dung amended soil as well as the control were low in essential nutrients like $\mathrm{N}$ and $\mathrm{P}$ in comparison to the soil treated with chemical (NPK) fertilizer (Table 1). Several literatures have linked the accumulation of phenolics, flavonoids and lycopene to the level of available $\mathrm{N}$ in the soil. For instance, Oliveira et al. (2013) and Mitchell et al. (2007) in their separate studies which investigated the effects of organic and inorganic fertilizers on plant secondary metabolites, reported that organically produced tomatoes accumulated higher concentrations of bioactive compounds like total phenolics and flavonoids compared to inorganically grown ones. These compounds have been reported to accumulate more in plants cultivated on organic manures due to low level of N (Mittler, 2002; Abd El-Moniem et al., 2012; Mohd et al., 2013). Numerous studies have explained that plants tend to produce more or higher level of bioactive compounds and antioxidant as a preventive or protective measure against oxidative and abiotic stress which may result from low level or slow release of macronutrient like N (Caris-Veyrat et al., 2004; Toor et al., 2006; Wang et al., 2008; Vallverdu-Queralt et al., 2012; Oliveira et al., 2013). This conclusion is backed up by several other studies on the nutritional quality of fruits and vegetables, which reported that organically produce have approximately three times less nitrate in comparison to conventional crops due to lower availability of nitrogen in organic farming systems (Worthington, 2001; Williams, 2002; Tuomisto et al., 2012).

The result of the current study is consistent with the above submissions as evident in the concentrations of phenolics, flavonoids and lycopene in the tomato fruits from control and cow dung amended soils, both growing media with lower level of available $\mathrm{N}$ compared to NPK fertilizer and chicken droppings. Whereas lower concentrations of total phenolic, flavonoid and lycopene were detected in the fruits harvested from soils amended with chicken droppings and NPK fertilizer, both growing media with higher level of available $\mathrm{N}$. It was therefore assumed that there is an inverse relationship between the concentration of bioactive compounds like phenolics, flavonoids, lycopene and the level of available $\mathrm{N}$ in the soil.

Other studies concluded that organic manures have stimulatory effect on the accumulation of bioactive compounds by inducing acetate shikimate pathway in biosynthesis, resulting in higher production of secondary metabolites like flavonoids and phenolics (Sousa et al., 2008; Yoldas et al., 2008). It must be noted that although the results of this study showed a significantly higher lycopene content in both the control and the organic cow dung amended soils, some studies have argued that, types 
of soil fertilization have no effect on lycopene content of fruits. It was explained that lycopene content is accumulated more in the deep ripen stage (Toor et al., 2006; Ilahy et al., 2011). The current study therefore identified this area for further studies in future research.

This study however showed a result of opposite pattern for beta-carotene which was significantly higher in the fruit cultivated in the soil treated with NPK fertilizer and closely followed by that from chicken droppings. This could be due to the higher content of available $\mathrm{P}$ in the NPK fertilizer and chicken droppings manure which has been reported to increase beta-carotene contents in fruits and vegetables (George and Zhou, 2002; Abd El-Baky, 2010). Furthermore, the action of phosphorus on enzymes like phosphofructokinase, pyruvate kinase and precursors of pyruvate has been linked with the biosynthesis of carotenoid (Bramely, 2002; Black et al., 2008). The study by Meysam et al. (2017) also reported that increased level of $\mathrm{P}$ application led to increase level of carotenoid production.

Although, there was no statistical significance in the potential ability to inhibit and retard oxidation processes, also known as radical scavenging activity of the fruits, it was however slightly higher in the fruits from the soil treated with cow dung. There is no conclusive report on what is responsible for higher production or stimulation antioxidant activity in plant. While some reports have suggested that organic production increases plant antioxidant activity (Janzantti et al., 2012; Vinha et al., 2014), other studies with similar observation to the current study have reported no significant difference in the antioxidant activity of plants from organic and conventional system of production (Fischer et al., 2007; Reche et al., 2019).

\section{Conclusion}

In general, this study demonstrated the responsiveness of bioactive compounds in tomato to the level of soil macronutrients which are relatively low or slowly released in organic amendments. It was observed that nitrogen content in the soil has a significant effect on the level of certain bioactive compound synthesis. Although, inorganic NPK fertilizer produced highest growth, yield and beta-carotene, control and organic cow dung amended soils had a higher stimulatory effect on the bioactive compounds like phenolic, flavonoid, lycopene and antioxidant activity. This study therefore concludes that in the effort to reduce environmental degradation through minimum dependence on chemical fertilizer, more usage of free and readily available organic manures as a source of soil fertility management should be recommended. The study also identifies that the link between method of farming system and other secondary metabolites as well as radical scavenging activity requires extensive and detailed study in future research.

Acknowledgements. The authors would like to thank the staff and management at the Sefako Health Sciences University as well as Agriculture Research Council (Vegetables and Ornamental Plants Unit). The funding from National Research Foundation (NRF) is also greatly appreciated.

\section{REFERENCES}

[1] Abd El-Baky, M. M. H., Ahmed, A. A., El-Nemr, M. A., Zaki, M. F. (2010): Effect of potassium fertilizer and foliar zinc application on yield and quality of sweet potato. Research Journal of Agricultural and Biological Sciences 6(4): 386-394. 
[2] Abd El-Moniem, M. N., Farouk, K. E., Zeinab, A. S., Hanaa, A. H., Hanaa, F. A., Alaa, A. G. (2012): Enhancement of phenolics, flavonoids and glucosinolates of Broccoli (Brassica olaracea) as antioxidants in response to organic and bio-organic fertilizers. Journal of the Saudi Society of Agricultural Sciences 11: 135-142.

[3] Aina, O. E., Olowoyo, J. O., Mugivhisa, L. L., Amoo, S. O. (2018): Effect of different soil amendments on growth performance and levels of Copper and Zinc in Lycopersicon esculentum. - Nature Environment and Pollution Technology 17(1): 255-259.

[4] Ayeni, O. (2014): Assessment of heavy metals in wastewaters obtained from an industrial area in Ibadan, Nigeria. - Materials and Geo-environment 61: 19-24.

[5] Baxter, A., Mittler, R., Suzuki, N. (2014): ROS as key players in plant stress signaling. Journal of Experimental Botany 65: 1229-1240.

[6] Bhonwong, A., Stout, M. J., Attajarusit, J., Tantasawat, P. (2009): Defensive role of tomato polyphenol oxidases against cotton bollworm (Hellicoverpa armigera) and beet armyworm (Spodoptera exigua). - Journal of Chemical Ecology 35: 28-38.

[7] Bieheler, E., Mayer, F., Hoffmann, L., Krause, E., Bohn, T. (2010): Comparison of spectrophotometric methods for carotenoid determination in frequently consumed fruits and vegetables. - Journal of Food Science 75: 55-61.

[8] Black, R. E., Allen, L. H., Bhutta, Z. A., Caulfield, L. E., de Onis, M., Ezzati, M., Mathers, C., Rivera, J. (2008): Maternal and child undernutrition: global and regional exposures and health consequences. - Lancet 371: 243-260.

[9] Bramely, P. M. (2002): Regulation of carotenoids formation during tomato fruit ripening and development. - Journal of Experimental Botany 53: 2107-2113.

[10] Camara, K. M., Payne, W. A. Rasmussen, P. E. (2003): Long term effects of tillage, nitrogen and rainfall on winter wheat yields in the Pacific Northwest. - Agronomy Journal 95: 828-835.

[11] Canene-Adams, K., Campbell, J. K., Zaripheh, S., Jeffery, E. H., Erdman, J. W. (2005): The tomato as a functional food. - Journal of Nutrition 135: 1226-1230.

[12] Caris-Veyrat, C., Amiot, M. P., Tyssandier, V., Grasselly, D., Buret, M., Mikolajczak, M. et al. (2004): Influence of organic versus conventional agricultural practice on the antioxidant microconstituent content of tomatoes and derived purees; consequences on antioxidant plasma status in humans. - Journal of Agricultural and Food Chemistry 52: 6503-6509.

[13] Chang, A., Lim, M., Lee, S., Robb, E. J., Nazar, R. N. (2008): Tomato phenylalanine ammonia-lyase gene family, highly redundant but strongly underutilized. - Journal of Biological Chemistry 283: 33591-33601.

[14] de Ponti, T., Rijk, B., Van Ittersum, M. K. (2012): The crop yield gap between organic and conventional agriculture. - Agricultural System 108: 1-9.

[15] Dumas, Y., Dadomo, M., Lucca, G., Grolier, P., di Lucca, G. (2003): Effect of environmental factors and agricultural techniques on antioxidant content of tomatoes. Journal of Science of Food and Agriculture 83: 369-382.

[16] Ekbic, H. B., Ozdemir, G., Sabir, A., Tangolar, S. (2010): The effects of different nitrogen doses on yield, quality and leaf nitrogen content of some early grape cultivars (V. vinifera L.) grown in greenhouse. - African Journal of Biotechnology 9: 5108-5112.

[17] Fischer, I. H., Arruda, M. C., Almeida, A. M., Garcia, M. J. M., Jeronimo, E. M., Pinotti, R. N., Bertani, R. M. A. (2007): Postharvest diseases and physical chemical characteristics of yellow passion fruit from organic and conventional crops in the region of Sao Paulo State. - Revista Brasileira de Fruticultura 29(2): 254-259.

[18] Fließbach, A., Oberholzer, H. R., Gunst, L., Mader, P. (2007): Soil organic matter and biological soil quality indicators after 21 years of organic and conventional farming. Agriculture Ecosystem and Environment 118: 273-284.

[19] George, M. S., Lu, G., Zhou, W. (2002): Genotypic variation for potassium uptake and utilization efficiency in sweet potatoes. - Field Crops Research 77: 7-15. 
[20] Guo, J., Liu, X., Zhang, Y., Shen, J., Han, W., Zhang, W. et al. (2010): Significant acidification in major Chinese croplands. - Science 327: 1008-1010.

[21] Hague, A. (2012): Effect of different organic manures on growth and yield of cabbage. Master Thesis, Department of Horticulture, Patuakhali Science and Technology University (PSTU) Patuakhali, Bangladesh.

[22] Hakkinen, S. H., Torronen, A. R. (2000): Content of flavonoids and selected phenolic acid in strawberries and vaccinium species: influence of cultivar, cultivation site and technique. - Food Research International 33: 517-524.

[23] Han, H., Zhao, L. (2009): Farmers' character and behaviour of fertilizer application evidence from survey of Xinxiang County Henan Province, China. - Agricultural Sciences in China 8(10): 1238-1245.

[24] Hebbar, S. S., Ramachandrappa, B. K., Najappa, H. V., Prabhakar, M. (2004): Studies of NPK drip fertigation in field grown tomato. - European Journal of Agronomy 21(1): 117127.

[25] Hughner, R. S., Pierre, M., Andrea, P., Julie, S. (2007): Who are organic food consumers? A cosmopolitan and review of why people purchase organic food. - Journal of Consumer Behaviour 6(2-3): 94-110.

[26] Hunter, D., Foster, M., McArthur, J. O., Ojha, R., Petocz, P., Samman, S. (2011): Evaluation of the micronutrient composition of plant foods produced by organic and conventional agricultural methods. - Critical Review in Food Science and Nutrition 51: 571-582.

[27] Ibrahim, M. H., Jaafar, H. Z. E., Karimi, E., Ghasemzadeh, A. (2013): Impact of organic and inorganic fertilizers application on the phytochemical and antioxidant activity of Kacip Fatimah (Labisia pumila B.). - Molecules 18: 10973-10988.

[28] Ilahy, R., Hdider, C., Lenucci, M. S., Tlili, I., Dalessandr, G. (2011): Phytochemical composition and antioxidant activity of high lycopene tomato (Solanum lycopersicum L.) cultivars grown in southern Italy. - Journal of Science and Horticulture 127: 255-261.

[29] Isah, A. S., Amans, E. B., Odion, E. C., Yusuf, A. A. (2013): Growth rate and yield of two tomato varieties (Lycopersicon esculentum Mill) under green manure and NPK fertilizer rate Samaru Northern Guinea Savanna. - International Journal of Agronomy 1: $1-8$.

[30] Janzantti, N. S., Macoris, M. S., Garruti, D. S., Monteiro, M. (2012): Influence of the cultivation system in the aroma of the volatile compounds and total antioxidant activity of passion fruit. - Food Science and Technology 46(2): 511-518.

[31] John, L. W., James, D. B., Samuel, L. T., Warner, L. W. (2004): Soil Fertility and Fertilizers: An Introduction to Nutrient Management. - Pearson Education, India, pp. 106-153.

[32] Johnson, E., Husain, A., Kuktaite, R., Anderson, S. C., Olsson, M. E. (2014): Contribution of organically grown crops to human health. - International Journal of Environmental Research 11: 3870-3893.

[33] Lima, G. P. P., Teixeira, da Silva, J. A., Bernhard, A. B., Pirozzi, D. C. Z., Fleuri, L. F., Vianello, F. (2012): Organic and conventional fertilization procedures on the nitrate, antioxidants and pesticides content in parts of vegetables. - Food Additives and Contaminants Part B 5(3): 188.

[34] Luis, A. (2015): ROS and RNS in plant physiology: an overview. - Journal of Experimental Botany 66: 2827-2837.

[35] Magkos, F., Arvanti, F., Zampelas, A. (2001): Organic food: Nutritious food or food for thought? A review of the evidence. - International Journal for Food and Nutrition 54: 357-371.

[36] Mani, J. (2002): Early Events in Environment Stresses in Plants: Induction Mechanisms of Oxidative Stress. - In: Inze, D., Montague, M. V. (eds.) Oxidative Stress in Plants. Taylor and Francis, New York, pp. 217-246. 
[37] Meysam, G. J., Mohsen, M., Issa, K., Maryam, R. (2017): The changes of yield and essential oil components of German Chamomile (Maticaria recutita L.) under application of phosphorus and zinc fertilizers and drought stress conditions. - Journal of the Saudi Society of Agricultural Sciences 16(1): 60-65.

[38] Mishra, D. N., Singh, L. R. (2006): Effect of N, P fertilization on the performance and production economics of rainfed okra intercropped with tomato under mid-hill condition. - Environment and Ecology 24(3): 546-550.

[39] Mitchell, A., Hong, Y., Koh, E., Barrett, D., Bryant, D., Denison, R., Kaffka, S. (2007): Ten-Year comparison of the influence of organic and conventional crop management practices on the content of flavonoids in tomatoes. - Journal of Agricultural and Food Chemistry 55: 6154-6159.

[40] Mitran, T., Mani, P. K., Bandyopadhyay, P. K., Basak, N. (2017): Influence of organic amendments on soil physical attributes and aggregate associated phosphorus under longterm rice wheat-cropping. - https://doi.org/10.1016/S1002-0160(17)60423-5.

[41] Mittler, R. (2002): Oxidative stress, antioxidants and stress tolerance. - Trends in Plant Science 7: 405-410.

[42] Mohd, H. I., Hawa, Z. E. J., Eshan, K., Ali, G. (2013): Impact of organic and inorganic fertilizers application on the phytochemical and antioxidant activity of Kacip Fatimah (Labisia pumila Benth). - Molecules 18(9): 10973-10988.

[43] Moyo, M., Amoo, S. O., Aremu, A. O., Gruz, J., Subrtova, M., Jarosova, M., Tarkowski, P., Dolzal, K. (2018): Determination of mineral constituents, phytochemical and antioxidant qualities of Cleome gynandra compared to Brassica oleracea and Beta vulgaris. - Frontier Chemistry 5: 128.

[44] Mózner, Z., Tabi, A., Csutora, M. (2012): Modifying the yield factor based on more efficient use of fertilizer - the environmental impacts of intensive and extensive agricultural practices. - Ecological Indicators 16: 58-66.

[45] Nafiu, A. K., Togun, A. O., Abiodun, M. O., Chude, V. O. (2011): Effects of NPK fertilizer on growth, dry matter production and yield of eggplant in southwestern Nigeria. - Agriculture and Biology Journal of North America 2(7): 11170-1125.

[46] Norman, U., Dazzo, F. B. (2016): Making rice production more environmentally friendly. - Environments 3(12): 1-7.

[47] Norse, D. (2005): Non-point pollution from crop production: global, regional and national issues. - Pedosphere 15(4): 1-10.

[48] Nouri, J., Mahvi, A. H., Jahed, G. R., Babaei, A. (2008): A regional distribution pattern of groundwater heavy metals resulting from agricultural activities. - Environmental Geology 55: 1337-1343.

[49] Oliveira, A. B., Moura, C. F. H., Gomes-Filho, E., Marco, C. A., Urban, L., Miranda, M. R. A. (2013): The impact of organic farming on quality of tomatoes is associated to increased oxidative stress during fruit development. - Plos One 8: e56354.

[50] Palozza, P., Parrone, N., Catalano, A., Simone, R. (2010): Tomato lycopene and inflammatory cascade: basic interactions and clinical implications. - Current Medicinal Chemistry 17: 2547-2563.

[51] Pinela, J., Barros, L., Carvalho, A. M., Ferreira, I. C. (2012): Nutritional composition and antioxidant activity of four tomato (Lycopersicon esculentum L.) Farmer's varieties in Northeastern Portugal homegarden. - Food and Chemical Toxicology 50: 829-834.

[52] Rai, R., Thapa, U., Mandal, A. R., Roy, B. (2013): Growth, yield and quality cabbage (Brassica Oleracea) as influenced by vermicompost. - Environmental Ecology 31: 314317.

[53] Reche, J., Hernandez, F., Almansa, M. S., Carbonell-Barrachina, A. A., Legua, P., Amoros, A. (2019): Effects of organic and conventional farming on the physicochemical and functional properties of jujube fruit. - LWT - Food Science and Technology 99: 438444. 
[54] Rice, A. L., West Jr, K. P., Black, R. E. (2004): Vitamin A Deficiency. - In: Ezzati, M., Lopez, A. D., Rodgers, A., Murray, C. J. L. (eds.) Comparative Quantification of Health Risks. Global and Regional Burden of Disease Attributable to Selected Major Risk Factors. World Health Organization, Geneva.

[55] Seufert, V., Ramankutty, N., Foley, J. A. (2012): Comparing the yields of organic and conventional agriculture. - Nature 485: 229-232.

[56] Sharma, P., Jha, A. B., Dubey, R. S., Pessarakli, M. (2012): Reactive oxygen species, oxidative damage, and antioxidative defense mechanism in plants under stressful control. - Journal of Botany ID 217037.

[57] Sierra, J. et al. (2015): Observed and predicted changes in soil carbon stocks under export and diversified agriculture in the Caribbean. The case study of Guadeloupe. - Journal of Agriculture, Ecosystem and Environment 213: 252-264.

[58] Simova-Stoilova, L., Demiresvka, K., Petrova, T., Tsenov, N., Feller, U. (2008): Antioxidative protection in wheat varieties under severe recoverable drought at seedling stage. - Plant Soil and Environment 54: 529-536.

[59] Singleton, V. I., Orthofer, R., Lamuela-Raventos, R. M. (1999): Analysis of total phenols and other oxidation substrates and antioxidants by means of Folin-Ciocalteu reagent. Methods in Enzymology 299: 152-178.

[60] Smith-Springer, C. S., Brandeau, M. L., Hunter, G. E., Bavinger, C. J., Person, M. B. S., Eschbasch, P. J., Sundaram, V., Liu, H., Schirmer, P., Stave, C., Olkin, I., Bavata, D. M. (2012): Are organic foods safer or healthier than conventional alternatives? - Annals of Internal Medicine 157: 348-366.

[61] Sousa, C., Pereira, D. M., Pereira, J. A., Bento, A., Rodrigues, M. A., Garcia, D. S. (2008): Multivariate analysis of Tronchuda cabbage (Brassica oleracea) phenolics: influence of fertilizer. - Journal of Agricultural and Food Chemistry 56: 2231-2239.

[62] Stephen, O., David, A. A., Abdullahi, A. B., Oludare, O. A. (2014): Effect of NPK and poultry manure on growth, yield, and Proximate composition of three amaranths. Journal of Botany ID 828750, 6 .

[63] Stuart, D., Schewe, R. L. McDermott, M. (2014): Reducing nitrogen fertilizer application as a climate change mitigation strategy: understanding farmer decision-making potential barriers to change in the US. - Land use Pollution 36: 210-218.

[64] Sultana, J., Siddique, M. A., Rashid, M. H. A. (2012): Effects of cow dung and potassium on growth and yield of Kohlrabi. - Journal of Bangladesh Agricultural University 10: 2732 .

[65] Taber, H., Perkins-Veazie, P., Li, S., White, W., Rodermel, S., Xu, Y. (2008): Enhancement of tomato fruit lycopene by potassium is cultivar dependent. - Hortscience 43: 159-165.

[66] Tarozzi, A., Hrelia, S., Angeloni, C., Morroni, F., Biagi, P., Guardigli, M., Cantelli-Forti, G., Hrelia, P. (2006): Antioxidant effectiveness of organically and non-organically grown red oranges in cell culture systems. - European Journal of Nutrition 45: 152-158.

[67] Toor, R. K., Savage, G. P., Heeb, A. (2006): Influence of diverse types of fertilizers on the major antioxidant components of tomatoes. - Journal of Food Composition and Analysis 19: 20-27.

[68] Tuomisto, H. L., Hodge, I. D., Riordan, P., Macdonald, D. W. (2012): Does organic farming reduce environmental impacts? A metal analysis of European research. - Journal of Environmental Management 112: 309-320.

[69] Vallverdu-Queralt, A., Jauregui, O., Medina-Remon, A., Lamuela-Raventos, R. M. (2012): Evaluation of a method to characterize the phenolic profile of organic and conventional tomatoes. - Journal of Agricultural Food Chemistry 60(13): 3373-3380.

[70] Vinha, A. F., Barreira, S. V., Costa, A. S., Alves, R. C., Oliveira, M. B. P. (2014): Organic versus conventional tomatoes influence on physicochemical parameters, bioactive compounds and sensorial attributes. - Food and Chemical Toxicology 67: 139144. 
[71] Wei, W. et al. (2018): Fertilizer N application rate impacts plant-soil feedback in a Sanqi production system. - Science of the Total Environment 633: 796-807.

[72] Wiebel, F., Bickel, R., Leuthold, S., Alfoldi, T. (2000): Are organically grown apples tastier and healthier? A comparative filed study using conventional and alternative methods to measure fruit quality. - Acta Horticulturae 57: 417-426.

[73] Williams, C. M. (2002): Nutritional quality of organic food: shades of grey or shades of green? - Proceedings of the Nutrition Society 61: 19-24.

[74] Witness, M., Ofentse, M., Thembinkosi, M., Gabathsele, M. L., Sifanele, M. (2016): Yield and yield attributes of tomato as influenced by organic fertilizer. - American Journal of Experimental Agriculture 12(1): 1-10.

[75] Worthington, V. (2001): Nutritional quality of organic versus conventional fruits, vegetables, and grains. - Journal of Alternative and Complementary Medicine 7: 161173.

[76] Yoldas, F., Ceylan, S., Yagmur, B., Mordogan, N. (2008): Effect of nitrogen fertilizer on yield quality and nutrient content in broccoli. - Journal of Plant Nutrition 31: 1333-1343.

[77] Zeinab, A. S., Farouk, K. E., Alaa, A. G., Mohamed, F. Z. (2013): Antioxidant activities of phenolics, flavonoids and vitamin $\mathrm{C}$ in two cultivars of fennel (Foeniculum vulgare) in responses to organic and bio-organic fertilizers. - Journal of Saudi Society of Agricultural Sciences 14: 91-99.

[78] Zeng, Y., Gao, Y., Tong, Y. (2011): Effect of $\mathrm{N}$ supply on the developments of $\mathrm{N}$ in leaves and new branches in Fuji apple. - Journal of Northwest Sci-Tech University of Agriculture 39: 197-201.

[79] Zhao, X., Nechols, J. R., Williams, K. A., Wang, W., Carey, E. E. (2009): Comparison of phenolics Acids in organically and conventionally grown pack-choi (Brassica rapa L. chinensis). - Journal of Science of Food and Agriculture 89: 940-946.

[80] Zhisten, J., Mengcheng, T., Jianming, W. (1999): The determination of flavonoid contents in mulberry and their scavenging effects on superoxide radicals. - Food Chemistry 64: 555-559.

[81] Znidarcic, D., Kacjan-Marsic, N., Osvald, J., Porzrl, T., Trdan, S. (2007): Yield and quality of early cabbage (Brassica leracea L. var. capitata) in response to within-row plant spacing. - Acta Agriculturae Slovenica 89: 15-23. 